overview of the subject, it should be a worthwhile addition to the steadily growing literature on legal anthropology.

\begin{abstract}
ARAB LAW
In view of an increasing interest in Arab law, it might be in the interest of the readers to mention four new books containing analyses and English translations of laws of the various countries on the Arab Peninsula: Business Laws of Kuwait by N. H. Karam, Business Laws of Saudi Arabia by N. H. Karam, Business Laws of the United Arab Emirates by M. J. Hall, and Property Lawe in the Arab World by F. J. Ziadeh (Professor and Chairman of the Near East Department of the University of Washington in Seattle). The first three titles are produced in looseleaf form and are supposed to be updated by regularly appearing supplements. All four books are published by Graham \& Trotman, Ltd., London, leading publishers of books providing information about Arab business and finance. The prices of all four of the above books are like the cost of oil. The books on business law are priced at $£ 53$ each ( $£ 94$ with an update service for the first year); Property Law in the Arab World costs $£ 26.50$. The publishers plan to issue two more law titles in the near future: The Development of Law in the Arabian Gulf and Legal Aspects of Business in Saudia Arabia.
\end{abstract}

\title{
COMPUTERIZED LEGAL INFORMATION RETRIEVAL SYSTEM IN GREAT BRITAIN
}

In 1979 the Society for Computers and Law recommended the establishment of a computer-assisted legal information retrieval system for the United Kingdom in a report entitled A National Law Library-The Way Ahead. The report was received favorably by both branches of the legal profession (the barristers and solicitors), as well as the judiciary, the government, and the law publishers. Now an organization has been formed to promote the establishment of a system. The new organization, named the National Law Library, is a corporate trust with charitable status. It is sponsored by the Law Society of England and Wales, the Law Society of Northern Ireland and the Bar Council, and the Society for Computers and Law. Lord Scarman is the first president of the trust. The actual development of the system is conducted by the National Law Library Limited as a fully-owned subsidiary of the National Law Library Trust.

The purposes of the National Law Library include the establishment of standards for organizations offering data bases to the legal profession, 
the encouragement and evaluation of legal information data base development, the setting up and operation of educational programs about computerized legal information retrieval for the legal profession, and the development of pilot schemes in the creation of data bases. A tax law data base has been announced as the first of such pilot schemes. For further information about the National Law Library, write to its offices at Inveresk House, 1 Aldwych, London, WC2ROHF, U.K.

In the meantime Mead Data Central, the producer of the LEXIS computerized legal information retrieval system in the United States, has announced the extension of LEXIS to English law.

The initial LEXIS English Library contains :

-English cases, reported in the Law Reports, All English Law Reports and Lloyd's Reports from 1945 to date.

-All tax cases reported in Simon's Tax Cases and Reports of Tax Cases.

In the near future LEXIS is also expected to add to the program a statutory library consisting of all general statutes and statutory instruments in force, a tax law library consisting of Inland Revenue press releases, extra-statutory concessions, and other tax-related documents, and an industrial law library.

In the United Kingdom LEXIS is offered by arrangement with Butterworth (Telepublishing) Ltd., and English lawyers have access to the complete LEXIS program, including all LEXIS files on American law. In the United States, the English files are available to all subscribers as a part of the regular service.

\section{UNITED STATES LEGISLATION ON FOREIGN RELATIONS}

The annual update volumes-Legislation on Foreign Relations Through 1979 have been published (Vol. I, February, 1980; Vol. II, March, 1980) as Joint Committee Prints of the House Committee on Foreign Affairs and the Senate Committee on Foreign Relations. These volumes contain current legislation and related executive orders. They are very valuable for scholars involved with or interested in foreign affairs. Vol. III, which contains treaties and was last published in 1977 is not being updated in the 1979 set. The volumes are published by the Government Printing Office in Washington, D.C.

\section{MULTINATIONAL CORPORATIONS : A NEW BIBLIOGRAPHY}

The Centre on Transnational Corporations at the United Nations in New York has published an over 400-page long, computer-produced 